\title{
PRODUKTIWITEIT EN VERANTWOORDELIKHEID, ENKELE SIELKUNDIGE ASPEKTE
}

\author{
A.P. VENTER \\ DEPARTEMENT BEDRYFSIELKUNDE \\ UNIVERSITEIT VAN DIE ORANJE VRYSTAAT
}

\section{SUMMARY}

\begin{abstract}
Some psychological aspects of Maslow's motivation theory are discussed with a view to pointing out the usefulness of this theory in the industrial situation. It is suspected that industrial psychologists do not always interpret Maslow's theory correctly. The aspect of responsibility in the need for selfactualization seems to be undervalued, in some instances completely unrecognized. A logical conclusion drawn is that self-actualization, in accordance with Maslow's own description, is related to productivity.
\end{abstract}

Die woord produktiwiteit lê deesdae op almal se lippe; die woord verantwoordelikheid skuil egter iewers in die gewete. Albei hierdie begrippe is egter vir die volkshuishouding só belangrik dat hulle nie geskei en oorbeklemtoon kan word nie. Bekyk vanuit die oogpunt van die bedryfsielkunde is produktiwiteit ' $n$ indiwiduele aangeleentheid, veral waar die indiwidu bewus is van die aard van produktiwiteit en wat sy posisie in hierdie opset is. Hierdie posisie van die indiwidu slaan op sy volle mensheid waarvan sekere aspekte miskien meer gewig dra as ander.

Produktiwiteit is maar een van vele ander oogmerke van 'n onderneming en alle werkkragte in die hiërargie dra indiwidueel en gesamentlik daartoe by om, in sy eenvoudigste definisie van produktiwiteit, uitsette in terme van arbeidsinsette te lewer.

\section{DIE INDIWIDUELE WERKER EN SY BEHOEFTES}

Die gevaar bestaan vandag dat die indiwiduele werker in die massa verswelg kan word. Tog behels groeppogings die bydraes van elke indiwidu in terme van sy vermoëns, besluite wat hy neem, sy houdings, en sy uiteindelike gedrag. Groeplidmaatskap is wel belangrik, veral waar die waarde in terme van groepsnorms besef word, maar wanneer die indiwidu vir werk aansoek doen, die indiwidu gekeur word, die indiwidu besluit om 'n kontrak met die 
werkgewer aan te gaan in terme van sy gewilligheid om werk-betrokke te raak, die indiwidu se persoonlike bydrae, sy verantwoording, sy invloed in die groep, geld, kan ons die posisie van die indiwidu nie misken nie. Hy word ook bevorder, opgelei, gemeriteer, tree uiteindelik af, of word selfs ontslaan.

Met betrekking tot die proses van arbeidsinsette-wat-opuitsette-uitloop, ontstaan die vraag: waaruit bestaan die indiwidu se bydrae?

In die eerste plek is 'n bewussyn van waarméé die indiwidu besig is, asook van hómself (wie en wat hy is en hoe hy in hierdie prentjie pas) aller noodsaaklik.

$\mathrm{Al}$ is dit so dat indiwidue grootliks van mekaar verskil in terme van hulle totale persoonlikhede, is daar tog tussen mense baie gemeenskaplikhede wat hulle dan tipies mense mak - te onderskei van alles wat nie mense is nie. In sy wete dat hy mens is, dat hy wel bestáán, en vanweë sy vermoë om hieroor te besin, word hierdie menslike bestaan vir elke indiwidu van allergrootste belang. Om as mens te bestaan en voort te bestaan, is daar tipies menslike behoeftes waarin voorsien moet word. Die totale mens behels egter meer as 'n blote fisiese aspek met fisiese behoeftes. Ten einde aan hierdie totaliteitsaard van die mens te voldoen, het verskeie wetenskaplikes behoefte-teorieë ontwerp en getoets waarvan Maslow (1970) se behoeftehiërargie nie alleen baie bekend is nie (al is die kennis daarvan oor die algemeen taamlik gebrekkig), maar ook 'n taamlik algemeen geldende teorie blyk te wees, in die sin dat dit die stempel van universaliteit dra. (Skrywer is bewus van sekere tekortkominge in die teorie, maar aanvaar terselfdertyd dat geen volmaakte siening ooit moontlik is nie). McGregor(1966) beskou Maslow se teorie as "the most fruitful approach I know", en bespreek die behoeftes kernagtig naamlik die fisiologiese en veiligheidsbehoeftes, die sosiale behoeftes, die ego-behoeftes en die selfverwesenlikingsbehoeftes. Belangrik is dit om daarvan bewus te wees dat hierdie behoeftes elkeen nie alleen spesifiek is nie, maar ook in hiërargiese samehang met mekaar verkeer waarvan die selfverwesenlikingsbehoefte die hoogste is. In breë trekke, maar nie altyd nie, domineer die laer behoefte die indiwidu se gedrag tot bevrediging voordat die hoër behoefte dominerend word. Nog belangriker, veral vir die indiwidu in die bedryfslewe en ook vir die bedryf in terme van produktiwiteit, sê Maslow (1965, p.8): "Everyone has the motivation to create and to work, every child, every adult". Hy is meer bekommerd oor die inhibisies en dit wat hierdie motivering blokkeer as oor die oorsake van kreatiwiteit. Laasgenoemde is vir hom 'n gegewe feit. By implikasie se Maslow dus dat sekere van sy behoeftes nie net vir sekere mense gereserveer is nie; dit kom by almal net in verskillende grade voor. 
Indien die indiwiduele werker bewus is van sy behoeftestruktuur soos deur Maslow uiteengesit, is dit nuttig om te weet watter rol dit in die hele werksopset speel of behoort te speel. Hierdie rol sal duideliker blyk uit 'n kort bespreking van byvoorbeeld die aard en implikasies van die selfverwesenlikingsbehoefte aan die hand van Maslow (1965) se eie woorde. Van hierdie bespreking moet samehang met die ander behoeftes egter nie uit die oog verloor word nie.

Maslow (1970, p.46) verwys na 'n "discontent" en "restlessness" wat ontwikkel "unless the individual is doing what he, individually, is fitted for". En verderaan: "What a man can be, he must be. He must be true to his own nature. This need we may call self-actualization.

Hierdie omskrywing van selfverwesenliking hou dan onmiddellik enkele implikasies vir sowel die werker as die werkgewer in.

\section{IMPLIKASIES VIR DIE WERKER}

Behoeftebevrediging lyk op die oog af na 'n selfsugtige daad waardeur die behoeftige dan tevrede gestel word. In selfverwesenliking word die stryd tussen selfsug en onselfsugtigheid egter opgelos, omdat die verinnerliking van dit waarvoor gewerk word, deel van die self word: die skeiding tussen die innerlike en uiterlike word opgehef, omdat dit wat gedoen word 'n uitdrukking van die ware self is.

Maslow is baie geïnteresseerd in die terapeutiese waarde van selfuitlewingswerk, omdat dit die spanning rondom selfsug verlig; deurdat die verinnerliking van iets belangrik daar buite (vir elke indiwidu na sy eie aard) daartoe lei dat die selfagting verhoog word en die indiwidu terselfdertyd as byproduk vreugde ondervind, werksvreugde wat tot lewensvreugde lei.

'n Verdere implikasie waarop Maslow wys, is dat selfuitlewing nie vanself kom nie. Eerder beklemtoon hy 'n sekere verantwoordelikheid as hy hierbo sê "he must be". Daar rus dus 'n verpligting op die indiwidu om dit te doen wat hy kan, m.a.w. waartoe hy in staat is. 'n Verontagsaming hiervan lei tot intrinsieke skuld en intrinsieke onbevoegdheid met die gevolge wat daaruit voortspruit. Hierdie aspek van selfverwesenliking waardeur "One must respond to one's fate or one's destiny ..... " word te dikwels verwaarloos en misgekyk; daarsonder word 'n uiters skewe beeld van Maslow se gedagte gevorm. Hy sê: "So - to recognize one's responsibility or one's work out there is like a love relationship, a recognition of belongingness, a Zusammenhang". (Op. cit., p.46). 
Hierdie verantwoordelikheid wat op die werker se skouers rus, eis ook dat hy sal vasstel waartoe hy in staat is, sodat hy daarin kan slaag om "something important from the world" te verinnerlik, en sodat hy daardeur self belangrik kan word, homself kan versorg, self respekteer. Dan beteken hy iets vir die samelewing. Dit herinner sterk aan Victor Frankl (1970) se logoterapie waardeur gepoog word om die mens se soeke na betekenis te bevredig. Volgens Maslow, sal dit dan te selfsugtig wees om byvoorbeeld selfmoord te pleeg omdat dit 'n verlies vir die wêreld daarbuite sal beteken.

\section{IMPLIKASIES VIR DIE WERKGEWER}

Die werkgewer is nie net werkgewer nie; as indiwidu geld alles wat hierbo gesê is, ook vir hom, maar hy is ook werkgewer op wie se skouers meer verantwoordelikhede rus ten einde te voldoen aan Maslow (1965,p.1) se "eupsychian management - proper management of the work lives of human beings, of the way in which they earn their living, can improve them and improve the world and in this sense be a utopian or revolutionary technique".

Die werker en werkgewer gaan 'n sielkundige kontrak (cf. Schein, 1970) aan in terme waarvan die werker sielkundige verwagtings koester, met ander woorde sielkundige uitlewing. Die sielkundige uitlewing hang ten nouste saam met die selfverwesenlikingsbehoefte - "the desire to become more and more what one idiosyncratically is" (Maslow 1970, p.46). Dit is dus ' $n$ behoefte met ' $n$ bestanddeel van groei of ontwikkeling daarin, asof dit nie versadig kan raak nie. Die werkgewer kan die werknemer nie motiveer nie, dit is ' $n$ innerlike dryfkrag in die indiwidu self, maar die werkgewer kan sorgdra vir die aansporingselemente in die onderneming ten einde vir die groei en ontwikkeling tot selfvervulling voorsiening te maak.

Benewens die voordele voortspruitende uit doeltreffende waarneming van die werklikheid, aanvaarding van sigself, ander en die natuur, spontane en natuurlike gedrag, probleem bo egosentriese belangstelling, selfstandigheid, voortdurende en verfrissende waardering vir dit wat die lewe bied, innige interpersoonlike verhoudinge, onderskeiding tussen goed en kwaad en middele en doelwitte en talle ander aspekte by die selfverwesenlikingsmens, kan die werkgewer veral reken op kreatiwiteit - "a universal characteristic of all the people studied or observed". (Maslow 1970, p. 170). Verontagsaming deur die werkgewer hiervan is skadelik vir sowel die werker as die onderneming en die gemeenskap as geheel. Maslow sien hierdie skeppingskenmerk ietwat anders as dit wat die sogenoemde geniale mens 
(byvoorbeeld Mozart) openbaar; hy vergelyk dit eerder met die "the naive and universal creativeness of unspoiled children" (1970, p.170). Alle werkers beskik dus in 'n sekere mate hieroor en die werkkondisies wat hierdie dryfveer ontsluit, sal ook die geniale mens se skeppinge verseker.

Ten einde die ewewig egter te behou, is dit wenslik om te let op Maslow se beklemtoning van die onvolmaaktheid van selfverwesenlikingsmense (1970, p.176). "Our subjects show many of the lesser human failings. They too are equipped with silly, wasteful, or thoughtless habits. They can be boring, stubborn, irritating ... ". Maslow het geleer "There are no perfect human beings".

Schein (1970, pp.50-79) bepleit 'n komplekse mensbeskouingsbenadering deur die werkgewer. Die klem hierbo op die selfverwesenlikingsbehoefte wil nie die ander behoeftes misken nie; dit is juis die erkenning van die samehang van die hele hiërargie wat tot Schein se konsep lei. Die klem word hier op die selfverwesenlikingsbehoefte geplaas uitsluitlik ten einde bloot enkele sielkundige aspekte in die kollig te bring, veral die verantwoordelikheidsaspek wat op sowel die werker as die werkgewer se skouers rus.

\section{SLOT}

Wanneer daar nou oor bogenoemde gedagtes besin word, is dit moeilik om volkome te aanvaar dat; "It is .... questionable whether Maslow's theory of motivation is adequate as a theory of work motivation" (Barling, 1977). Maslow se teorie is sekerlik nie volmaak nie, maar 'n bloot intuïtiewe insig sê tog vir 'n mens dat hierdie teorie plek in die bedryfsituasie het en dat ' $n$ indringende kennis, besef en benutting daarvan seersekerlik tot hoër produktiwiteit behoort te lei. (Trouens, reeds in 1950 het Fouriezos, Hutt en Guetzkow 'n verband tussen produktiwiteit en die groeibehoefte (selfverwesenliking) gevind). Die mens se motiveringslewe is ten volle geïntegreer met sy hele persoonlikheid; hy beskik tog nie oor verskillende stelle motiverings wat in verskillende situasies aan- en afgeskakel word nie.

Totdat die teendeel bo alle twyfel bewys is kan die praktisyn met groot vrug kennis neem van hierdie motiveringsteorie en stappe in terme daarvan doen. Sukses daarmee is egter afhanklik van 'n deeglike insig daarin, en 'n onbevooroordeelde benadering. 


\section{OPSOMMING}

Maslow se motiveringsteorie wat uit die kliniese sielkunde ontspruit het, is ook deur bedryfsielkundiges van nader beskou, veral in hoe verre dit met produktiwiteit verband het. Enkele sielkundige aspekte word bespreek ten einde op die nut van hierdie teorie in die bedryfsituasie te wys. Die vermoede bestaan dat die teorie deur bedryfsielkundiges nie altyd korrek vertolk word soos Maslow dit self uiteensit nie; veral word die verantwoordelikheidsaspek in die selfuitlewingsbehoeftes misken en nie verreken nie; 'n Logiese konklusie is dat selfuitlewing, soos deur Maslow beskryf, wel verband met produktiwiteit het.

\section{VERWYSINGS}

Barling, J. A critical review of the application of Maslow's motivation theory in industry. Perspektiewe in Bedryfsielkunde, 1977 3(1), 3-36.

Fouriezos, N.T., Hutt, M.L.M. en Guetskow, H. A measurement of Self-orientated needs in discussion groups. Journal of Abnormal Social Psychology, 1950, 45, 682-690.

Frankl, V.E. Man's Search for Meaning, an Introduction to Logotherapy. (Hersiene uitgawe) Hodder \& Staughton, 1970.

Maslow, A.H. Eupsychian Management: a Journal. N.Y.: Irwin, 1965.

Maslow, A.H. Motivation and Personality. (Tweede uitgawe van 1954-bron) N.Y.: Harper \& Row, 1970.

McGregor Douglas. Leadership and Motivation. Cambridge, Mass: M.I.T. Press, 1966.

Schein, E.H. Organizational Psychology. N.Y.: Prentice-Hall, 1970. 